\title{
The Shadow Economy in Palestine: Size and Causes
}

\author{
Mahmoud M. Sabra ${ }^{1}$, Abdel Hakeem Ahmad Eltalla ${ }^{2} \&$ Abdel Rahman Alfar ${ }^{1}$ \\ ${ }^{1}$ Faculty of Economics and Administrative Sciences, Alazhar University, Gaza, Palestine \\ ${ }^{2}$ Faculty of Business and Finance, Alaqsa University, Gaza, Palestine \\ Correspondence: Abdel Hakeem Ahmad Eltalla, Faculty of Business and Finance, Alaqsa University, Gaza, \\ Palestine. E-mail: hakeemeltalla@hotmail.com
}

Received: November 25, 2014

doi:10.5539/ijef.v7n3p98

\author{
Accepted: December 13, 2014 \\ Online Published: February 25, 2015 \\ URL: http://dx.doi.org/10.5539/ijef.v7n3p98
}

\begin{abstract}
The study aims to measure the size of the shadow economy in Palestine during the period 1995-2012 by using multiple regression method. In addition, the study aims to assess the main reasons that affect the size of the shadow economy. By using latest data and multiple regression method, this paper finds that, the size of shadow economy is between $(57 \%-88 \%)$ of GDP. The size of shadow economy in Palestine is very high due to the political situation, which are a result of the Israeli occupation since 1967 and the blockade of Gaza strip. The main factors that affect the size of the shadow economy in Palestine is the ownership of businesses, an increase of ownership by $1 \%$ to the total employment leads to an increase in the shadow economy size by $0.57 \%$. Another important reason that affects the size of the shadow economy is the tax burden. According to our results, an increase of tax burden by $1 \%$ leads to an increase in the shadow economy size by $0.54 \%$. Other factors that affect the size of shadow economy in Palestine like the unemployment rate; growth rate and intensity of regulations are included in our study and have a significant effect. The shadow economy in Palestine plays a negative role that decreases the tax collections and affects the governmental fiscal policies.
\end{abstract}

Keywords: shadow economy, Palestine, tax burden, regulations

\section{Introduction}

The shadow economy is very important for the economy for the reason that it has significant consequences on the many segments of economic and social life of a population. The shadow economy, which consists of all market based lawful economic activities that are intentionally hidden from the government, is a big occurrence in many countries including Palestine. The growth of the shadow economy, across the developed and the developing countries, has underlined the significance of understanding the connection between the official and shadow economies. With raise in tax rates to finance big public spending programs, the appeal to evade taxes and regulatory restrictions increased. Crucial problem regarding the economic performance of the developing countries is the inadequate enforcement of tax collection and the existence of a large shadow economic activates. Along with other macroeconomic implications, the existence of a large shadow economy effects the selection of fiscal policy tools and government tax revenues. The shadow economic activities can deceive the policymakers. They affect the structure of the tax systems, it may entail restriction to the public revenues generation and, therefore, constraint the public services. On the positive side, the shadow economic activities allow avoiding intense regulations and offer a substitute social safety. The shadow economy (all the economic activity that adds value, but evades the official process of calculations.) is a prevailing phenomenon all over the world, and virtually all countries are attempting to restrain these activities. This is due to weaken and diminishing impacts on the tax base and social security systems. Schneider (2005) evaluated the scale of the shadow economy. He estimated its size from $7.9 \%$ of GDP in the United States to $66.4 \%$ in Georgia. The Shadow economy sum to about $15 \%$ of GDP in OECD economies on average, while in rest of the world is approximately $35 \%$. Schneider (2014) considered the results of the average size of the shadow economy of the 27 European Union countries, he estimated the shadow economy in the year 2003 was $22.3 \%$ of the GDP, declined to $19.3 \%$ in 2008 and grew to $19.8 \%$ in 2009 and then declined to $18.4 \%$ in 2013. The average of 31 European countries, in 2003 was $22.4 \%$, declined to $19.4 \%$ in 2008, and grew to $19.9 \%$ in 2009 and declined to 18.5 in 2013. In 2013 the shadow economy of Australia, Canada, Japan, New Zealand and the USA, had an average size of 8.6\%, in 2010 this rate was $9.7 \%$. In general, the shadow economic activities are recognized for low productivity and investments, poor working conditions, long and uncertain working hours, minimal wages, inadequate market conditions and 
institutional support. In Palestine, approximately $92 \%$ of construction labor force works in a shadow economic activities (MAS, 2006), this statistic gives a wide importance for the shadow economy against the official economy. The substantial shadow economy in developing nations is connected to a number of important problems, which may lead to reduced economic growth (Besley \& Persson, 2010). The shadow economy is also important in developed nations. The debt crisis in Greece has exposed the negative effects of a significant shadow economy. Portugal, Spain and Italy, as well face a significant budgetary difficulties. To deal with such problems, governments have two choices: reduce expenditures or boost revenues. Reducing expenditures is problematical and hard to achieve, mainly due to the danger of undermining the social texture, while improving revenues necessitates a strong tax base, which is weakened by the shadow economy. Under those conditions, a sizeable shadow economy may steadily jeopardize the economic and social stability. Governments, who have budgetary pressure including Palestine, are expected to look for useful catalysts to control the shadow economy in order to enhance the tax base and ease their budget restraint. A Valuable approach to reduce the shadow economy is improving the tax and social security structures. Substitute strategies to restrain the shadow economic activities are law and penalty, which could enhance the official economy. Another recognized policy mechanism is to lessen the regulatory liability in the official economy, which is one of the key reasons for the movement into the shadow economy. Further tools are to improve the ability and the confidence in the official institutions, to ensure property rights, and to improve the competence of public good condition (Torgler \& Schneider, 2009).

In this paper, we estimate the size of the shadow economy in Palestine over the period 1995 to 2012 by using an econometric model. Given the size of the shadow economy, we verify the role of socioeconomic, political and institutional factors in explaining the size of the shadow economy. The rest of the paper is organized as follows: First, we define the shadow economy. Second, we present the literature review on the shadow economy. Third, we present different methods to estimate the shadow economy. Forth, the data and the theoretical model are described. Fifth, the model is run and the results are presented. Finally, in the conclusions the main outcomes of our research are presented.

\section{Definition of the Shadow Economy}

The leading difficulty in studying the shadow economy is to define it. Researchers seeking to determine the size of the shadow economic activities face the question of the definition. Different definitions have been adopted. Schneider (1986) sums this point by defining the shadow economy as all economic activities that add to the value added and should be contained in national income but are currently not recorded by government agencies. Feige (1990) defined the Shadow Economy as:

"The economy that comprises those economic activities that circumvent the costs and are excluded from the benefits and rights incorporated in the laws and administrative rules covering property relationships, commercial licensing, labor contracts, torts, financial credit and social security systems.” (Feige, 1990, pp. 10).

Feige (1994) defined the Shadow Economy as all activities that add to the confirmed or determined calculation of the GDP but that they are not recorded. Smith (1994) described the Shadow Economy as the creation of goods and services founded on the market, legal or illegal, which eludes detection of the official calculation of the GDP: "Market-based production of goods and services, whether legal or illegal, that escapes detection in the official estimates of GDP" (Smith, 1994, pp. 4). Schneider and Enste (2000) defined Shadow Economy as the activities that would be taxed if they were informed to tax authorities. Blades and Roberts (2002) defined Shadow Economy as the economic activities that should be admitted in the GDP, but for different reasons are concealed by the statistical analyzes and accounting records where the national accounts are created. There are four causes for these activities not to be registered: tax evasion; illegal activities (e.g.: drugs); production of goods for own consumption; incomplete statistical and accounting records. Schneider (2005) defines the shadow economy as including all market-based legal production of goods and services. That are intentionally hidden from public authorities to evade payment of income, value added or other taxes, to evade payment of social security contributions, to evade some legal labor market standards ( minimum wages, safety standards), or to evade some administrative procedures. The shadow economy might be defined as all market based but hidden income from the creation of legal goods and services, both from financial or barter transactions, which generally is taxable if they were reported to public authorities. Schneider (2007) defined the Shadow Economy to include all the legal creation of goods and services on a market basis that is purposely hidden from public authorities for these reasons: to evade paying taxes; to refrain from standards of the labor market or to refrain from the fulfilment of statistical questionnaires or other forms. Thus, the Shadow Economy does not consider criminal activities (drug traffic, theft, etc) and it does not contain the informal household production. Schneider (2008) defined the Shadow Economy as follows: "All currently unregistered economic activities those contribute to the officially 
calculated (or observed) Gross National Product" (Schneider, 2008, p. 90).

\section{Literature Review}

A social anthropologist, Hart $(1971,1973)$ was the first to introduce the expression informal sector into the academic literature, as a fragment of the urban labor force outside of the formal labor market. The introduction of the informal sector concept included activities that were in the past ignored in academic models of development and in national economic accounts (Bromley \& Gerry, 1979). The shadow economy is of immense importance for researchers. There is a great deal of literature on its estimation measures and causes. Schneider and Enste (2000) examined the determinants of the shadow economy and they estimated its value for many countries. Frey and Weck-Hanneman (1984) utilized Multiple Indicator Multiple Cause approach (MIMIC) for the estimation of the shadow economy of 17 OECD countries for the period of 1960 to1978. They ranked the OECD countries according to the size of their shadow economy. Houston (1987) constructed a theoretical model of the business cycle and tax and monetary policy connection with the shadow economy. He found that the shadow economy impact should be considered in establishing tax and regulatory policies. The shadow economy also may lead to exaggeration of the inflationary impacts of monetary or fiscal stimulus policies. Friedman et al., (2000) argued that this negative relationship resulted according to an analysis tested the relation between the two variables over a period of time in different countries. Ahmed et al. (2007) confirmed the strong relation among income inequality and the shadow economic activities worldwide. They found no connection among tax rates and the shadow economy, but found a robust relation among tax rates and income equality. Rosser et al. (2003) demonstrated that income inequality is correlated strongly and significantly with the size of the shadow economy in the transition economies. Filho and Estevao (2012) used two methods to estimate the size of shadow economy in Brazil through the period of 2003 to 2011, those two methods were the monetary approach and the labor market approach. Filho estimated the size of Brazilian shadow economy between 15\%-20\% of GDP. Schneider and Buehn (2012) found a strong and significant positive relationship between self-employment as a causal variable for increasing the shadow economy size in 39 countries. Schneider (2008) evaluated the scale of the shadow economy in 2005. He estimated its size from $7.9 \%$ of GDP in the United States to $66.4 \%$ in Georgia. The Shadow economy sum to about $15 \%$ of GDP in OECD economies on average, while in rest of the world is approximately $35 \%$.

\section{Methods to Estimate the Shadow Economy}

As a modern topic in economic studies, estimating the shadow economy is not an easy assignment because it is a hidden activity. As a result, economists and researchers found that they could measure the size of the shadow economy by three methods, the direct method, the indirect method and the econometric modeling method.

\subsection{The Direct Method}

The direct method depends on observation and analysis for the unannounced information about income. The direct method estimates the shadow economy size by two ways.

\subsection{The Surveys and Questionnaires}

In this method a formal entity design and implement a survey, its targeted group can be all the society. There are some advantages such as the amount of the gathered information, which can help in more details to describe, estimate and then find some means to solve this economic problem. On the other hand, this method have disadvantages, e.g. if the questioned make wrong answers, as a result, the survey results could yield unreliable conclusions. (Ogunc \& Yilmaz, 2000). In Palestine, people generally used to hide their personal and financial information as a behaviour against the occupation; consequently, it is difficult to depend on the survey method to estimate the shadow economy size. The reason behind that is: some or all the provided information will contain incorrect data, as a result that could lead to misleading information.

\subsection{The Auditing Method}

Authorities can make estimation for the undeclared taxable income, then estimate the gap between declared and undeclared income to measure the tax evasion, which is an indicator for the size of shadow economy. Then the size of shadow economy related positively with the size of tax gap. This method has drawbacks, e.g., estimating the undeclared taxable income is not an easy mission and lies under personal estimations (Easton \& Veldhuis, 2001). Another drawback is that the tax gap could be considered as one proxy of group of proxies that indicate the size of the shadow economy, in other words it is not the only cause or indicator. In summary, using a technique to estimate the shadow economy in a direct method holds some disadvantages that cannot lead to appropriate results. 


\subsection{The Indirect Method}

Usually the indirect method uses macroeconomic indicators in order to draw an image for the status of the shadow economy over the time. For that, we can estimate the shadow economy size in an indirect way by using some techniques. This method includes five categories:

1) Discrepancy between national expenditure and income statistics (Gross domestic product approach).

2) The discrepancy between the official and actual statistics of labor force (Employment approach).

3) The transaction approach (Fisher's equation).

4) The currency demand (or cash-deposit ratio) approach.

5) The physical input (e.g. Electricity) method. (Dell'Anno, 2003).

\subsection{Gross Domestic Product Approach}

There are three methods to estimate the gross domestic product (GDP): The product method, the expenditure method and the income method. Logically, these three methods should lead to the same result, but the existence of the shadow economy creates some discrepancies. Usually, the result of the GDP method, which calculated by income and product methods, always lowers than the expenditure method. The idea for the gross domestic product approach is to calculate the discrepancy between the GDP which calculated by income or production method from one side and the GDP which calculated by expenditure method. More difference between the two sides leads to higher size of the shadow economy. This approach has some drawbacks, first, when statisticians minimize the discrepancy between the two methods, the results will be misleading. Another drawback, the non-disposable income that earned from the shadow economy activities and transferred to outside the country or saved as a foreign currency will minimize the GDP which calculated by expenditure method, therefore, it could lead again to misleading information as the estimated shadow economy size lower than the actual one. (Ogunc \& Yilmaz, 2000; Schneider \& Enste, 2000). Using this approach need to monitor every step and details when the GDP were calculated, for that, implying this approach on developing countries is a hard mission.

\subsection{Employment Approach}

If we assume that the labor force participation is constant (ceteris paribus), then, any decline in the labor force at the official economy will be face by an increase in the labor force in the shadow economy. The drawbacks of this approach are we assumed that other factors, which may affect the labor force, are constant, whereas in fact they are not. Another drawback might result a misleading conclusions. When some people work in the official economy and at the same time at the shadow economy, the size of the shadow economy will increase, while the labor force participation did not decrease. At the same time, this approach has an advantage; the calculation method of this approach is simple (Schneider \& Enste, 2000; Ogunc \& Yilmaz, 2000).

\subsection{The Transaction Approach}

This method depends on that specifies the equality between the total volume of payments $\left(\mathrm{M}^{*} \mathrm{~V}\right)$ and the total volume of product (PY): where $\mathrm{M}$ is the total quantity of money outside banks in a certain period of time, $\mathrm{V}$ is the velocity of money, $\mathrm{P}$ is the price index and $\mathrm{Y}$ is the quantity of goods and services that are exchanged in a certain period. The idea of Transaction approach is that the discrepancy between the total volume of payments $\left(\mathrm{M}^{*} \mathrm{~V}\right)$ and the total volume of product $(\mathrm{PY})$ provide an indirect index for the shadow economy activities size (Feige, 1990). One of the drawbacks for the Transaction approach is that there is no accurate estimation for the quantity of goods and services that exchanged in a certain period (Y). Therefore, a misleading conclusion might occur by using this approach. It is obvious that using this approach for highly developed countries might lead to meaningful results, however, in weak executive authorities regions might lead to incorrect results.

\subsection{The Currency Demand Approach (CDA)}

The basic assumption for this approach is that all shadow economy activities performed by using cash payments. The main reason for using the cash is to hide income from the government especially in developed countries, whereas, in developing countries they rely on cash for both the formal and the shadow economy transactions (Feige, 1990). By revising the currency demand ratio (C\D) over the time, we can find a constant ratio. Therefore, any change in this ratio will be attributed to the shadow economy activities, hence, any increase in currency demand will result an increase in the shadow economy size.(Ogunc \& Yilmaz, 2000).

\subsection{The Physical Input Approach}

This approach based on physical inputs e.g the electricity as an indicator for the overall economic activities, whether they were hidden or announced. Now, if there is a difference between growth of electricity consumption 
and the growth of domestic product; then, the difference can be used as a proxy about the shadow economy growth. This approach has some drawbacks: first, not all the shadow economy activities need electricity to operate, even the activities that need electricity to be operated could be performed by using alternative resources e.g. gas, petrol ...etc. The second drawback, this approach is a proxy for the shadow economy growth not the size, hence, we cannot compare between shadow economy sizes around the world by using this approach (Vuletin, 2008).

\section{Methodology and Data}

This study used the descriptive method to illustrate the theoretical frame by reviewing the previous literatures and analyse the secondary collected data from official entities such as the Palestinian central bureau of statistics, the Palestinian ministry of finance and the World Bank. Then, we used an econometric model that consider the real GDP as a dependent variable, and the tax burden, unemployment rate, the Growth rate and business characteristics as an independent variable. After testing the model fitness, the level of significance and determining the coefficients, we estimated the real GDP by using the model data to compare the real GDP and the estimated GDP by the Palestinian Central Bureau of Statistics in order to measure the size of the shadow economy in Palestine.

\subsection{The Model}

In this section, we are going to establish the econometric model to test the relationship between the dependent variable and the independent ones. As mentioned in the literatures, the dependent variable will be the GDP in constant prices while the independent variables are:

- Tax burden: the expected sign for the relationship between tax burden and the size of shadow economy is $(+)$.

- Unemployment rate: the expected sign for the relationship between unemployment rate and the size of shadow economy is $(+)$.

- Growth rate: the expected sign for the relationship between economic growth rate and the size of shadow economy is (-).

- Ownership: the expected sign for the relationship between ownership and the size of shadow economy is $(+)$.

The model will be as follow:

$$
Y=f(T b, U n E, G r, O)
$$

Where: $Y$ is the dependent variable, the real GDP, $T b$ is Tax burden, $U n E$ is Unemployment rate, $G r$ is Growth rate and $O$ is Ownership.

In this research we tried to apply our model by using linear regression but the results were not significant enough, so we moved to use the logarithmic formula (Gelman \& Hill, 2006).

The model equation:

$$
\log \left(Y_{t}\right)=c+\beta_{1} \log \left(T b_{t}\right)+\beta_{2} \log \left(U n E_{t}\right)+\beta_{3} \log \left(G r_{t}\right)+\beta_{4} \log \left(O_{t}\right)+\varepsilon_{t}
$$

Where: $\mathrm{C}$ : is the constant part of the equation $\beta_{1}, \beta_{2}, \beta_{3}, \beta_{4}$ : are the independent variables parameters and $\varepsilon_{t}$ : Random errors.

From this equation, we can predict the real GDP according to the existed data in order to estimate the size of shadow economy by the following equation:

$$
\lambda=10^{\log \left(Y_{t}\right)}
$$

Where, $\lambda$ is the Predicted real GDP

$$
\theta_{t}=\frac{\left(\lambda_{t}-Y_{t}\right)}{\lambda_{t}}
$$

$\theta$ : Informal economy as percentage of GDP.

\subsection{The Data}

All the data will be tested during the period 1995 to 2012 through the Palestinian territories (the West Bank and Gaza strip). We got the model variables for the estimation purposes from the official sides, where GDP from Ministry of finance, unemployment levels, level of economic development and Business characteristics are collected from the Palestinian Central Bureau of Statistics PCBS.

There are different reasons that affect the size of the shadow economy; the most important causes are taxes and social security burden, intensity of regulations, unemployment levels, level of economic development, and 
Business characteristics.

\subsubsection{Taxes and Social Security Burden}

Many researches refer to direct and indirect tax and social security burden as the main cause of shadow economy increase (Capasso \& Jappelli, 2013; Schneider \& Enste, 2000; Schneider, 2010). If tax rates are high, workers will be discouraged to work extra hours for their employer's benefit, instead of that they may accept to work in a low part time job standards in order to evade paying tax and earn more income. On general, Taxpayers will provide there accurate income statements at the exact time only if they receive efficient services from the public sector, and that is what known as the Tax moral (Buehn \& Schneider, 2012). Shadow economic activities will increase if the difference between labor earnings before and after tax were bigger than the formal economy. The tax burden will be considered as the percentage of total tax revenues divided by the real GDP, an increase in this portion means an increase in tax burden. Table 1 shows the total tax revenue and its percentage of real GDP in Palestine during the period of 1995-2012.

Table 1. Taxes in Palestine during the period 1995-2010

\begin{tabular}{cccccc}
\hline Year & $\begin{array}{c}\text { Total tax revenue } \\
\text { \$ million dollar }\end{array}$ & Total tax / GDP & Year & $\begin{array}{c}\text { Total tax revenue } \\
\text { \$ million dollar }\end{array}$ & Total tax / GDP \\
\hline 1995 & 357.0 & $11.1 \%$ & 2004 & 750.2 & $17.9 \%$ \\
1996 & 585.3 & $17.8 \%$ & 2005 & 957.1 & $20.9 \%$ \\
1997 & 502.4 & $13.4 \%$ & 2006 & 992.0 & $22.9 \%$ \\
1998 & 613.8 & $14.6 \%$ & 2007 & 1098.0 & $24.1 \%$ \\
1999 & 780.8 & $17.2 \%$ & 2008 & 1398.1 & $28.6 \%$ \\
2000 & 846.3 & $20.4 \%$ & 2009 & 1404.3 & $26.8 \%$ \\
2001 & 198.3 & $5.2 \%$ & 2010 & 1641.0 & $28.7 \%$ \\
2002 & 275.4 & $8.3 \%$ & 2011 & 1906.2 & $29.7 \%$ \\
\hline
\end{tabular}

Source: Ministry of Finance (2013).

The tax revenues were affected by the Political and the economic situation in Palestine. The ratio of tax Revenues as a percentage of GDP was increased from 1995-2000 according to an economic growth which took place at this period. However, in 2000, the Palestinian second intifada affected the economic growth rate and then the tax collections that reached the minimum level ever. Then, a recovery period from 2002 to 2008 showed a continuous increase in tax/GDP ratio before stabilization in this ratio from 2009 to 2012.

\subsubsection{Intensity of Regulations}

Another important reason that increases the shadow economy activities is the intensity of regulations, when employers receive the governmental regulations they will turn this burden into their employees. These actions work as a motivation for employees to move and work in shadow economy where no regulations burdens are. (Ogunc \& Yilmaz, 2000). The relationship between intensity of regulations and the shadow economy size as a percentage of GDP is positive, thus, more regulations issued by the government mean greater shadow economy size. The governments should concern more about effective implementation and combatable laws, rather than issuing new regulations (Schneider, 2010). The World Bank and The Doing Business Project which measures the business regulations and their enforcement across 189 economies around the world assessed. The Ease of doing business index at the Palestinian economy in West Bank and Gaza Strip were difficult. In 2012 Palestine placed as 145 of 189 country according to the Ease of doing business index where Jordan placed as 119 and Israel 33. In 2013 the Index of Palestine were improved to 138, and in Jordan still stable to 119, whereas in Israel there was a light negative change to the place 35. Unfortunately, the lack of information about the ease of doing business index which started up for first time in 2012 will not allow us to use this index at our model. Another important indicator of the World Bank which we are going to use as an indicator for intensity of regulations in Palestine is the Cost of company registrations as a percentage of GDP per capita. 
Table 2. Cost of company registration's in Palestine as a percentage of GDP per capita

\begin{tabular}{cccc}
\hline Year & \% of GDP per capita & Year & \% of GDP per capita \\
\hline 2003 & $81.7 \%$ & 2008 & $55.0 \%$ \\
2004 & $82.7 \%$ & 2009 & $93.7 \%$ \\
2005 & $108.7 \%$ & 2010 & $96.0 \%$ \\
2006 & $96.6 \%$ & 2011 & $91.0 \%$ \\
2007 & $69.1 \%$ & 2012 & $85.5 \%$ \\
\hline
\end{tabular}

Source: World Bank (2013).

\subsubsection{Unemployment Levels}

Some studies showed that there is a positive relationship between unemployment rate and the underground economy activities. A Canadian study about the shadow economy showed that the increase of unemployment rate in 1990 had affected the shadow economy to be increased (Smith, 1994). In Palestine, we can find high unemployment rates, which demonstrate our assumption in this research; there is a positive relationship between unemployment rate and increasing the size of shadow economy.

Table 3. The unemployment rates in Palestine during the period 1995-2012

\begin{tabular}{cccc}
\hline Year & Unemployment rate $\%$ & Year & Unemployment rate $\%$ \\
\hline 1995 & $18.2 \%$ & 2004 & $26.8 \%$ \\
1996 & $23.8 \%$ & 2005 & $23.5 \%$ \\
1997 & $20.3 \%$ & 2006 & $23.6 \%$ \\
1998 & $14.4 \%$ & 2007 & $21.6 \%$ \\
1999 & $11.8 \%$ & 2008 & $25.9 \%$ \\
2000 & $14.1 \%$ & 2009 & $24.6 \%$ \\
2001 & $25.2 \%$ & 2010 & $23.8 \%$ \\
2002 & $31.3 \%$ & 2011 & $20.9 \%$ \\
2003 & $25.6 \%$ & 2012 & $23.0 \%$ \\
\hline
\end{tabular}

Source: PCBS, (2013a).

Table 3 shows that the unemployment rates in Palestine through the period 1995-2012 in general were high, before the Palestinian second Intifada in 2000, the unemployment rates were lower than any other periods. The political situation affected the unemployment rates and pushed them higher.

\subsubsection{Level of Economic Development}

Another factor that affects shadow economy activities is the Gross Domestic Product growth rate as an indicator for economic development. if there is a potential economic growth, people most likely will work in formal economy rather than work in the shadow economy. In contrast, if the economy faces a recession period, people will search to redress their income loss at any shadow economy activity. (Schneider et al., 2010). Table 4 shows the Palestinian domestic product and its growth rate in constant prices by considering the year 2004 as the base year during the period of 1995-2012.

Table 4. Palestinian GDP and its growth rate in constant prices (the base year: 2004)

\begin{tabular}{cccccc}
\hline Year & GDP million\$ & Growth rate & Year & GDP million\$ & Growth rate \\
\hline 1995 & $3,212.40$ & $5.73 \%$ & 2004 & $4,198.40$ & $10.47 \%$ \\
1996 & $3,292.80$ & $2.50 \%$ & 2005 & $4,559.50$ & $8.60 \%$ \\
1997 & $3,744.00$ & $13.70 \%$ & 2006 & $4,322.30$ & $-5.20 \%$ \\
1998 & $4,197.70$ & $12.12 \%$ & 2007 & $4,554.10$ & $5.36 \%$ \\
1999 & $4,534.90$ & $8.03 \%$ & 2008 & $4,878.30$ & $7.12 \%$ \\
2000 & $4,146.70$ & $-8.56 \%$ & 2009 & $5,239.30$ & $7.40 \%$ \\
2001 & $3,810.80$ & $-8.10 \%$ & 2010 & $5,724.50$ & $9.26 \%$ \\
2002 & $3,301.40$ & $-13.37 \%$ & 2011 & $6,421.40$ & $12.17 \%$ \\
2003 & $3,800.50$ & $15.12 \%$ & 2012 & $6,797.30$ & $5.85 \%$ \\
\hline
\end{tabular}

Source: PCBS, (2013 b). 
The second intifada in 2000 affected the Palestinian economic growth rate, the GDP growth rate sharply fall down to be negative. In 2003, the Palestinian economy achieved the best growth rate in history before passing through the Palestinian legislative elections era in 2006 when the unstable economic conditions took place. After 2008 the economic growth rate were increased in a slowly matter before it was sloped down again in 2012 .

\subsubsection{Business Characteristics}

The shadow economy size may be affected by the Business characteristics: ownership, size of business and type of finance. Dell'Anno and Schneider (2004) showed that the higher the rate of self-employed the larger is the shadow economy, ceteris paribus. Schneider and Buehn (2012) assessed self-employment as a causal variable for increasing the shadow economy size in 39 country, they found a strong and significant positive relationship. For the size of the business we can found that there is a negative relationship between the size of the business and the size of shadow economy, thus, small enterprises activities are most likely act in shadow economy. In this research we are going to use the variable ownership as an index for business characteristics which affect the size of shadow economy in Palestine.

\subsubsection{Ownership (Self-Employed)}

As mentioned previously, self-employment enhance the chance of increasing the size of shadow economy (Schneider \& Buehn, 2012). In Palestine, we can find a high Self-employed percentage to the overall work force. In general, the self-employed percentage in Palestine was from 17.9\% to 26.8\% among the period 1995-2011.

Table 5. Self-employed as a percentage of total labor force in Palestine

Source: PCBS, (2013a).

\begin{tabular}{cccc}
\hline Year & Self-employed & Year & Self-employed \\
\hline 1995 & $21.2 \%$ & 2004 & $26.5 \%$ \\
1996 & $22.3 \%$ & 2005 & $26.1 \%$ \\
1997 & $22.9 \%$ & 2006 & $25 \%$ \\
1998 & $21.0 \%$ & 2007 & $24.2 \%$ \\
1999 & $18.7 \%$ & 2008 & $20.7 \%$ \\
2000 & $19.6 \%$ & 2009 & $19.2 \%$ \\
2001 & $24.0 \%$ & 2010 & $18.8 \%$ \\
2002 & $26.8 \%$ & 2011 & $18.6 \%$ \\
2003 & $27.8 \%$ & 2012 & $17.9 \%$ \\
\hline
\end{tabular}

During the second intifada the indicators of self-employed were increased, and this might be due the closure of the Israeli cross points which did not allow the Palestinian workers to reach their works in Israel. After the closure, the Palestinian workers moved to find new job opportunities, so some of them worked as a self-employed and self-financed. In years later, the political situation in West Bank become better, so many workers went back and got their jobs in Israel. In Gaza strip a consequent era of tunnels between the Palestine-Egypt borders was started. In 2007, many workers moved from their works even if they are self-employed and may self-financed to work in goods transfer from Egypt to Palestine where they can get high income.

\section{Coefficients of the Model and the Results}

The determinant coefficient of the model is 0.763 , the value of determinant coefficient should lie between 0 and 1. This means that, the model explains $76 \%$ of the variability of the response data around its mean. Indeed, when we try to explain Adjusted R square we can found it (0.69) which means the model explains $69 \%$ of the variability of the response data around its mean. The other percentage, which not included in the model, is due other factors, which we have not an accurate information about it. ANOVA test used usual to test the model fitness, at level of significance equals to .05 we accept the alternative assumption that agrees the model fitness. 
Table 6. Results of the regression analysis

\begin{tabular}{|c|c|c|c|c|c|}
\hline & Sum of squares & Df & Mean square & $\mathrm{F}$ & significant \\
\hline Regression & .113 & 3 & .028 & 10.448 & .001 \\
\hline Residual & .035 & 13 & .003 & & \\
\hline \multirow[t]{2}{*}{ Total } & .149 & 17 & & & \\
\hline & Standardized coefficients Beta & $\mathrm{T}$ & & & significant \\
\hline Constant (4.00) & & 11.191 & & & .000 \\
\hline Tax Burden & .545 & 3.467 & & & .004 \\
\hline Unemployment Rate & .301 & 1.860 & & & .086 \\
\hline Growth rate & -.282 & 2.027 & & & .064 \\
\hline Ownership & .570 & -3.113 & & & .008 \\
\hline
\end{tabular}

Source: Own results.

From Table 6 The value of independent variable "Tax Burden" $X_{1}$ Coefficient is (.545), which means, the raise of Tax Burden by 1 percent leads to an increase of Shadow economy size by (.545) percent, at the level of significance equals to .01. This result agrees with the literatures. The tax burden was a main reason for increasing the size of shadow economy. The value of independent variable "Unemployment Rate" $X_{2}$ Coefficient is (.301), which means, the raise of Unemployment Rate by $1 \%$ leads to an increase of the shadow economy size by $\% 0.301$, at the level of significance equals to 0.1 .

The value of independent variable "Growth rate" $X_{3}$ Coefficient is (.282), which means, the raise of "Growth rate" by $\% 1$ leads to a decrease of Shadow economy size by $0.282 \%$, at the level of significance equals to 0.1 , the negative sign refer to the kind of relation and have no effect on the values. The value of independent variable "Ownership" $X_{4}$ Coefficient is (.570), which means, the raise of Ownership by $1 \%$ leads to an increase of the shadow economy size by $0.570 \%$, at the level of significance equals to .01 .

From the coefficient table we can re-write the equation as follow:

$$
\log \left(Y_{t}\right)=4+0.545 \log \left(T b_{t}\right)+0.301 \log \left(U n E_{t}\right)-0.282 \log \left(G r_{t}\right)+0.570 \log \left(O_{t}\right)+\varepsilon_{t}
$$

From this equation, we can predict the real GDP according to the existed data in order to estimate the size of shadow economy by the following equation:

$$
\lambda=10^{\log \left(Y_{t}\right)}
$$

Where, $\lambda$ is the Predicted real GDP

$$
\theta_{t}=\frac{\left(\lambda_{t}-Y_{t}\right)}{\lambda_{t}}
$$

$\theta$ : Informal economy as percentage of GDP.

The following table shows the Predicted real GDP, GDP by constant prices, the informal economy as a

\begin{tabular}{|c|c|c|c|c|c|c|c|}
\hline Year & Predicted GDP & Official GDP & $\begin{array}{c}\text { Shadow economy } \\
\text { as } \% \text { of GDP }\end{array}$ & Year & Predicted GDP & Official GDP & $\begin{array}{c}\text { Shadow economy } \\
\text { as } \% \text { of GDP }\end{array}$ \\
\hline 1995 & 12686779 & 3212400 & $74.68 \%$ & 2004 & 32583196 & 4198400 & $87.11 \%$ \\
\hline 1996 & 17459987 & 3292800 & $81.14 \%$ & 2005 & 29251543 & 4559500 & $84.41 \%$ \\
\hline 1997 & 20960212 & 3744000 & $82.14 \%$ & 2006 & 26110900 & 4322300 & $83.45 \%$ \\
\hline 1998 & 14325035 & 4197700 & $70.70 \%$ & 2007 & 24305558 & 4554100 & $81.26 \%$ \\
\hline 1999 & 10696012 & 4534900 & $57.60 \%$ & 2008 & 31741808 & 4878300 & $84.63 \%$ \\
\hline 2000 & 14663981 & 4146700 & $71.72 \%$ & 2009 & 28151555 & 5239300 & $81.39 \%$ \\
\hline 2001 & 13742373 & 3810800 & $72.27 \%$ & 2010 & 29742798 & 5724500 & $80.75 \%$ \\
\hline 2002 & 27086146 & 3301400 & $87.81 \%$ & 2011 & 28580496 & 6421400 & $77.53 \%$ \\
\hline 2003 & 33586896 & 3800500 & $88.68 \%$ & 2012 & 24492982 & 6797300 & $72.25 \%$ \\
\hline
\end{tabular}
percentage of GDP and the size of shadow economy through the period 1995 to 2012 in Palestine.

Table 7. The size of shadow economy in Palestine using an econometric model

Source: the authors' calculations. 


\section{Conclusions}

After revising the literatures, testing the causes of shadow economy and there weights and measuring the size of the shadow economy; this research reached some results as following: The size of the shadow economy in Palestine by using an econometric model is between (57.6\%-88.7\%) of GDP. The shadow economy in Palestine as it plays a negative role that decreases the tax collections and affects the governmental fiscal policies. On general, the size of shadow economy in Palestine is very high due to the political situation which is a result of the Israeli occupation since 1967, the blockade policy which taken against Gaza strip from 2006 and the Palestinian separation from 2007 until now. In addition, the internal economic conditions also played a critical role in increasing the size of shadow economy. The main factor that affect the size of the shadow economy in Palestine is the ownership of businesses, in other words an increase of ownership percentage to the total employment by $1 \%$ leads to an increase in the shadow economy size by $0.57 \%$. Another important reason that affects the size of the shadow economy in Palestine is Tax burden. According to our results, an increase of tax burden percentage by $1 \%$ leads to an increase in the shadow economy size by $0.545 \%$. Other factors that affect the size of shadow economy in Palestine like the unemployment rate, growth rate and intensity of regulations are included in our study and have a significant effect.

\section{References}

Ahmed, E., Rosser Jr, J. B., \& Rosser, M. V. (2007). Income inequality, corruption, and the non-observed economy: A global perspective. In Complexity Hints for Economic Policy (pp. 233-252). Milan: Springer. http://dx.doi.org/10.1007/978-88-470-0534-1_12

Besley, T., \& Persson, T. (2010). State capacity, conflict, and development. Econometrica, 78(1), 1-34. http://dx.doi.org/10.3982/ECTA8073

Blades, D., \& Roberts, D. (2002). Measuring the non-observed economy. Statistics Brief, 5.

Bromley, R., \& Gerry, C. (1979). Casual work and poverty in third world cities (p. 323). Chichester: Wiley.

Buehn, A., \& Schneider, F. (2012). Size and Development of Tax Evasion in 38 OECD countries: What do we (not) know? (No. 4004). CESifo Working Paper: Public Finance. Retrieved from http://hdl.handle.net/10419/68196

Capasso, S., \& Jappelli, T. (2013). Financial development and the underground economy. Journal of Development Economics, 101, 167-178. http://dx.doi.org/10.1016/j.jdeveco.2012.10.005

Easton, S., \& Veldhuis, N. (2001). The size of the underground economy: A review of the estimates. Simon Fraser University.

Feige, E. L. (1990). Defining and estimating underground and informal economies: The new institutional $\begin{array}{lllll}\text { economics } & \text { approach. } & \text { World } & \text { Development, } & \text { 18(7), }\end{array}$ http://dx.doi.org/10.1016/0305-750X(90)90081-8

Feige, E. L. (1994). The underground economy and the currency enigma. Public Finance, 49, 119-136.

Filho, \& Estevão, M. (2012). Institutions, Informality, and Wage Flexibility: Evidence from Brazil (EPub) (No. 12-84). International Monetary Fund.

Frey, B. S., \& Weck-Hanneman, H. (1984). The hidden economy as an 'unobserved'variable. European Economic Review, 26(1), 33-53. http://dx.doi.org/10.1016/0014-2921(84)90020-5

Friedman, E., Johnson, S., Kaufmann, D., \& Zoido-Lobaton, P. (2000). Dodging the grabbing hand: The determinants of unofficial activity in 69 countries. Journal of Public Economics, 76(3), 459-493. http://dx.doi.org/10.1016/S0047-2727(99)00093-6

Gelman, A., \& Hill, J. (2006). Data analysis using regression and multilevel/hierarchical models. Cambridge University Press. http://dx.doi.org/10.1017/CBO9780511790942

Hart, K. (1970). Small-scale entrepreneurs in Ghana and development planning. The Journal of Development Studies, 6(4), 104-120. http://dx.doi.org/10.1080/00220387008421338

Hart, K. (1973). Informal income opportunities and urban employment in Ghana. The Journal of Modern African Studies, 11(1), 61-89. http://dx.doi.org/10.1017/S0022278X00008089

Houston, J. F. (1987). Estimating the size and implications of the underground economy (No. 87-9).

Mas. (2006). Informal Construction Services in the Palestinian Territories: Current Status and Prospects.

Ogünç, F., \& Yılmaz, G. (2000). Estimating the underground economy in Turkey. The Central Bank of Turkey 
Discussion Paper September.

Palestinian Central Bureau of Statistics (PCBS). (n.d.). Retrieved from http://www.pcbs.gov.ps/

Palestinian Ministry of Finance. (n.d.). Retrieved from http:/www.pmof.gov.ps/

PCBS. (2013a). Unemployment Rate Among labour Force Participants in the Palestinian Territory Governorates and Sex, 1999-2012.

PCBS. (2013b). Major National Accounts Variables by Region for the Years 1994-2012 at Constant Prices: 2004 is the base year.

Rosser, J. B., Rosser, M. V., \& Ahmed, E. (2003). Multiple unofficial economy equilibria and income distribution dynamics in systemic transition. Journal of Post Keynesian Economics, 25(3), 425-448.

Schneider, F. (1986). Estimating the size of the Danish shadow economy using the currency demand approach: An attempt. The Scandinavian Journal of Economics, 643-668. http://dx.doi.org/10.2307/3440435

Schneider, F. (2005). Shadow economies around the world: What do we really know? European Journal of Political Economy, 21(3), 598-642. http://dx.doi.org/10.1016/j.ejpoleco.2004.10.002

Schneider, F. (2008). The shadow economy in Germany: A blessing or a curse for the official economy? Economic Analysis and Policy, 38(1), 89-111. http://dx.doi.org/10.1016/S0313-5926(08)50008-7

Schneider, F. (2013). Size and Progression of the Shadow Economies of Turkey and Other OECD Countries from 2003 to 2013; Some New Facts. Ekonomi-tek-International Economics Journal, 2(2), 83-116.

Schneider, F. (2014). Size and Development of the Shadow Economy of 31 European and five other OECD countries from 2003 to 2013: A further decline.

Schneider, F., \& Buehn, A. (2013). Estimating the size of the shadow economy: Methods, problems and open questions (No. 1320). Working Paper, Department of Economics, Johannes Kepler University of Linz. Retrieved from http://hdl.handle.net/10419/97444

Schneider, F., \& Enste, D. (2000). Shadow economies around the world-size, Causes, and Consequences. International Monetary Fund.

Smith, P. (1994). Assessing the size of the underground economy: The statistics Canada perspective. National Accounts and Environment Division, Statistics Canada Division des comptes nationaux et de l'environnement, Statistique Canada.

Torgler, B., \& Schneider, F. (2009). The impact of tax morale and institutional quality on the shadow economy. Journal of Economic Psychology, 30(2), 228-245.

Torgler, B., Schneider, F., \& Schaltegger, C. A. (2010). Local autonomy, tax morale, and the shadow economy. Public Choice, 144(1-2), 293-321. http://dx.doi.org/10.1016/j.joep.2008.08.004

Vuletin, G. (2008). Measuring the Informal Economy in Latin America and the Caribbean. International Monetary Fund, IMW Working Paper WP/08/102, Washington D.C. http://dx.doi.org/10.1007/s11127-009-9520-1

World Bank. (2013). World Bank Open Data. Retrieved from http://data.worldbank.org

\section{Copyrights}

Copyright for this article is retained by the author(s), with first publication rights granted to the journal.

This is an open-access article distributed under the terms and conditions of the Creative Commons Attribution license (http://creativecommons.org/licenses/by/3.0/). 